American Journal of Applied Sciences 6 (6): 1093-1105, 2009

ISSN 1546-9239

(C) 2009 Science Publications

\title{
Sustainable Production Process of Biological Mineral Feed Additives
}

\author{
${ }^{1}$ Agnieszka Zielińska, ${ }^{1}$ Katarzyna Chojnacka and ${ }^{2}$ Marjana Simonič \\ ${ }^{1}$ Institute of Inorganic Technology and Mineral Fertilizers, Wroclaw University of Technology, \\ Smoluchowskiego 25, 50-372 Wroclaw, Poland \\ ${ }^{2}$ Faculty of Chemistry and Chemical Engineering, University of Maribor, \\ Smetanova 17, SI-2000 Maribor, Slovenia
}

\begin{abstract}
Problem statement: This study discussed the problem of accumulation of $\mathrm{Zn}$ and $\mathrm{Cu}$ in the topsoil as a result of application of mineral feed additives that possess low bioavailability in animal diet. The review considered the production process of mineral feed additives in which a product supplies microelements in highly bioavailable form. Enrichment of natural biomass of edible microalgae with microelement metal ions, which supply microelements of feeding significance in livestock diet, is considered in term of sustainable production. Approach: Production of microalgaederived products as mineral feed additives requires elaboration of the processes for cultivation of alga, enrichment process and afterwards recovery of the enriched biomass from the solution to obtain liquid free of cells that could be reused in the next process. In this study membrane bioreactor was considered as a method for separation, both in photobioreactor (growth of microorganism) as well as in the enrichment process. Results: Effort involved in thermal and chemical separation techniques is higher than that in mechanical techniques. Membrane bioreactors which are usually applied to treat wastewater, both industrial and domestic. This study discussed method to separate a valuable biomass of enriched microalgae and reuse the solution with residual metal ions that can be used once again in the subsequent biosorption process. Conclusion/Recommendation: Taking into consideration care about the environment it is better to apply membrane modules in the production process in terms of sustainable production. The proposed solution assumed the application of membrane modules as a separation step after enrichment process and biomass recovery.
\end{abstract}

Key words: Microalgae, mineral feed additives, biosorption, bioaccumulation, microelements, membrane bioreactors

\section{INTRODUCTION}

Each process in food and agriculture industry has an impact on the environment and there is much concern about environmental pollution ${ }^{[1]}$.The intensification of agricultural production in Poland is expected to increase dramatically in the next few years as a result of entry of Poland to the EU. This rapid economical and technological push can lead to increased soil pollution with heavy metals $(\mathrm{Zn}$ and $\mathrm{Cu}$ ) caused by application of organic fertilizers as it is in the case of Western Europe. The high content of those metals in manure is caused by an elevated content in animal feed. It is very important to reduce heavy metals load in manure by lowering the in-flux through animal feed. It is necessary to utilize Western Europe experience to avoid this danger ${ }^{[2]}$.
Among the majority of new technologies that have appeared since the 1970s, biotechnology perhaps attracted the most attention. Biotechnology can supply useful products that can replace conventional agrochemicals or enhance their effectiveness so that their overall consumption is reduced ${ }^{[3,4]}$. Increase of environmental awareness is a fact, many businesses have responded to this awareness by providing "greener" products and using "greener" processes. In addition, biotechnology can provide animal feeds with enhanced nutritional composition and keep quality, to improve the sustainability of animal production ${ }^{[5]}$.

Designing new product and its production methods we should have the best interests of the globe in mind. Industrial sustainability aims to achieve sustainable production and processing within the context of ecological and social sustainability ${ }^{[5,6]}$. Many natural

Corresponding Author: K. Chojnacka, Institute of Inorganic Technology and Mineral Fertilizers, Wroclaw University of Technology, Smoluchowskiego 25, 50-372 Wroclaw, Poland Tel: +48-71-3204325 Fax: +48-71-3203469 
processes are in a dynamic equilibrium in which negative feedback loops, remaining in a relatively steady state in which fluctuations in the prosperities of the environment are absorbed or leveled off by counterreactions by the system ${ }^{[7]}$. Additionally, sustainable development concepts have resulted in increasing environmental pressure to improve the efficiency of resources utilization and significantly reduce waste generation and emissions ${ }^{[8]}$.

The aim of the present study was to show the possibility of reduction of the risk of increasing amount of heavy metals in soil against of intensification of agriculture industry by implementation of mineral feed additives in form of bioplex of microelements and the microalgal biomass, instead of inorganic salts, as well as application of membrane bioreactors in production process of such a product.

\section{MATERIALS AND METHODS}

In order to assess the possibility of application of microalgae in animal feeding and membrane bioreactor, to make the production process more sustainable, the peer-reviewed literature and official reports were examined. To compile available data on membrane bioreactors related to production of mineral feed additives, over hundred reports, abstracts and papers were studied which document the microelement in animal nutrition, biosorption and bioaccumulation process in enrichment of microalgae and membrane bioreactors application in terms of sustainability. The information are summarized in the following chapters: $\mathrm{Cu}$ and $\mathrm{Zn}$ in animal feeding: environmental effects, Biomass enrichment via biosorption and bioaccumulation, Microalgae in Terms of Sustainable Production, MBR Technology, MBR in microalgal technology and MBR in Production Process where the proposition of production process was given.

\section{RESULTS}

$\mathrm{Cu}$ and $\mathrm{Zn}$ in animal feeding: environmental effects: The ecological view of sustainability focuses on preserving the resilience and dynamic ability of biological and physical systems to adapt to change ${ }^{[8]}$. The environmental performance of agriculture has become a key issue in Poland. This study investigates the ways to minimize its effects on the environment. Intensive animal breeding is considered to be a serious obstacle to sustainable development. $\mathrm{Cu}$ and $\mathrm{Zn}$ are often oversupplied in animal diets because they are used as growth promoters or because large safety margins are applied as a result of low bioavailability. Consequently, manure is highly concentrated in these elements, which may concentrate in top soil and cause toxicity to plant and microorganisms ${ }^{[9]}$. We may feed an animal $5.51 \mathrm{~kg}$ of protein per day, if the digestibility of that protein is only $65 \%$ though it is actually only receiving about $3.58 \mathrm{~kg}$. The same is true with minerals. Absorption rates may range from $0-99.5 \%$ depending on the source as well as a host of other factors. Application of highly bioavailable, bio-metallic feed additives based on microalgal biomass is one of the means to limit this environmental risk.

Because zinc and copper play so many important roles in the body, they are required by all livestock and poultry. Absorption of zinc ranges from 5-40\%. Estimated copper availability for grazed forage, silage and hay were $1.4,4.9$ and $7.3 \%$, respectively. Common sources of supplemental zinc include zinc sulfate, zinc oxide, zinc chloride, zinc carbonate and zinc chelates. There are the traditional inorganic sources of copper: copper sulfate, copper chloride, copper carbonate, copper oxide and then the organic sources defined by the organic molecule to which they were bound. Recent comparisons of bioavailability in chicks suggest that feed grade zinc oxide has only $44-78 \%$ the availability of zinc sulfate ${ }^{[10,11]}$. Many researchers have been studying relevant bioavailability of organic sources of copper and zinc. Marked differences in bioavailability between organic and inorganic formulations have been documented. Relative availability estimates for organic sources of copper ranged up to $147 \%$ of the response to cupric sulphate ${ }^{[11-15]}$.

Repeated land-applied animal manure causes accumulation of $\mathrm{Zn}$ and $\mathrm{Cu}$ (added to animal feed as feed supplements) in soils and may become toxic to plants (Table 1). These elements are also of concern because they can have an impact on human and environment ${ }^{[16,17]}$. Production of manure (solid and liquid) in 2002 reached $173.310^{6} \mathrm{t}$ in Poland. Annual heavy metal input into the environment via animal manure is not high but with the development that is expected, problems related with heavy metals contamination of soils fertilized by organic manure might become similar to those observed in Western agriculture (Table 1) ${ }^{[8]}$.

According to Institute of Soil Science in Pulawy, six levels of soil contamination with heavy metals are considered. First two categories are perceived as safe for human and environment (Table 1). The quality the soil in Polish agriculture is very good in terms of heavy metals concentration, (97\% " 0 " and " 1 " category) ${ }^{[8]}$.

When manure is applied at high rates or composted and then applied at lower rates, all of the trace minerals 
Am. J. Applied Sci., 6 (6): 1093-1105, 2009

Table 1: Six levels of soil contamination with heavy metals input of heavy metals though land-applied ${ }^{\text {a }}$ hazardous concentration affecting $50 \%$ of the species at their $\mathrm{EC}_{50}$ level

\begin{tabular}{|c|c|c|c|c|c|c|c|c|c|}
\hline \multirow[b]{4}{*}{ Element } & & & & & \multicolumn{4}{|c|}{ Heavy metal input $\mathrm{g} \mathrm{ha}^{-1}$ year $^{-1[8]}$} & \multirow{4}{*}{$\begin{array}{l}\text { Log terrestrial } \mathrm{HC}_{50} \\
\mathrm{mg} \mathrm{kg}^{-1} \text { soil }^{[18]}\end{array}$} \\
\hline & \multirow{2}{*}{\multicolumn{4}{|c|}{$\begin{array}{l}\text { Indices of pollution of surface layers } \\
\text { of soil } \mathrm{mg} \mathrm{kg}^{-1[8]}\end{array}$}} & \multicolumn{2}{|l|}{ Poland } & \multicolumn{2}{|c|}{ Denmark } & \\
\hline & & & & & \multirow{2}{*}{$\begin{array}{l}\text { Animal } \\
\text { manure }\end{array}$} & \multirow{2}{*}{$\begin{array}{l}\text { Mineral } \\
\text { fertilizers }\end{array}$} & \multirow{2}{*}{$\begin{array}{l}\text { Animal } \\
\text { manure }\end{array}$} & \multirow{2}{*}{$\begin{array}{l}\text { Mineral } \\
\text { fertilizers }\end{array}$} & \\
\hline & Soil & 0 & $\mathrm{I}$ & $\mathrm{II}-\mathrm{V}$ & & & & & \\
\hline \multirow[t]{3}{*}{$\overline{\mathrm{Cu}}$} & $\mathrm{L}$ & 10 & 30 & $\geq 50$ & 21.4 & 4.11 & 218 & 17.9 & 2.54 \\
\hline & M & 20 & 50 & $\geq 80$ & & & & & \\
\hline & $\mathrm{H}$ & 25 & 70 & $\geq 100$ & & & & & \\
\hline \multirow{3}{*}{$\mathrm{Zn}$} & $\mathrm{L}$ & 50 & 100 & $\geq 200$ & 91.6 & 28.3 & 641 & 25.7 & 2.58 \\
\hline & M & 70 & 150 & $\geq 300$ & & & & & \\
\hline & $\mathrm{H}$ & 100 & 250 & $\geq 500$ & & & & & \\
\hline
\end{tabular}

Table 2: Differences between biosorption and bioaccumulation processes ${ }^{[25,30,31]}$

\begin{tabular}{|c|c|c|}
\hline & Bioaccumulation & Biosorption \\
\hline Cells type & Living cells & Dead cells \\
\hline Technology & Easier technologically & $\begin{array}{l}\text { Complicated } \\
\text { technologically }\end{array}$ \\
\hline Desorption & Not possible & Possible \\
\hline Rate & Low & High \\
\hline Place & $\begin{array}{l}\text { Intra and extracellular } \\
\text { space }\end{array}$ & $\begin{array}{l}\text { Extracellular } \\
\text { Space }\end{array}$ \\
\hline $\begin{array}{l}\text { Activation } \\
\text { energy }\end{array}$ & $63 \mathrm{~kJ} \mathrm{~mol}^{-1}$ & $21 \mathrm{~kJ} \mathrm{~mol}^{-1}$ \\
\hline Sensitivity & Nutrient dependent & $\begin{array}{l}\text { Independent of } \\
\text { specific } \\
\text { nutrients }\end{array}$ \\
\hline
\end{tabular}

excreted are incorporated into the soil. Agronomists have begun to study the availability of the trace minerals in soil and their impact on the concentrations in plants. Initial research suggests that the amount of copper and zinc in soil will influence the amount taken up by some crops ${ }^{[10]}$. Consequently, feeding trace mineral sources with high bioavailability is good for the animal and good for the environment. Bio-metallic feed additives from microalgae with designed composition are proposed to be a solution to problems with increasing accumulated quantities of trace element in the environment. Application of this kind of new generation of bio-metallic feed additives would supply microelements in highly bioavailable to animals form and would reduce amount of microelements of transit character used as supplements in animal fodders.

Biomass enrichment via biosorption and bioaccumulation: The biomass of microalgae is going to be enriched with microelements via biosorption and bioaccumulation processes. In this case microalgal biomass acts as a carrier of trace minerals in livestock diet. Biosorption and bioaccumulation are known as a selective and effective methods of pollutants removal from waste water ${ }^{[19-21]}$. In this study the processes are discussed as techniques of binding metal ions to the biomass of microalgae which are important in animals feeding.

Process of binding of microelements to the biomass (biosorption or bioaccumulation) is based on the ability of biological materials to accumulate metal ions by either metabolically mediated or purely physicochemical pathways of uptake ${ }^{[22]}$. Because of negative surface charge and membrane composition, organisms are natural adsorbents of metal ions ${ }^{[23]}$. Cell wall of microorganisms, consisting mainly of polysaccharides, proteins and lipids, offers many functional groups (such as carboxylate, hydroxyl, thiol, sulphonate, phosphate, amino and imidazole groups) that can form coordination complexes with metal cations ${ }^{[24,25]}$ and these functional groups are able to react with metal ions in aqueous solution ${ }^{[26]}$. Generally, the binding of metal ions by the biomass could be described as a two-step process where the metal was initially taken up onto the surface of the cell (biosorption) followed by the bioaccumulation inside the cell due to the metal uptake metabolisms ${ }^{[27]}$. Fist stage can be performed by both, living and dead organisms ${ }^{[26]}$, biosorption is either metabolism independent, such as physical or chemical sorption onto the microbial cell walls, or metabolism associated, such as transport, internal compartmentalization and extracellular precipitation by metabolites $^{[28]}$. Bioaccumulation occurs in two stages, biosorption where metal ions bind to the cell wall via an ion exchange mechanism and metal ion transportation into the cellular interior ${ }^{[29]}$. The main differences between biosorption and bioaccumulation are shown in Table 2.

Biosorption is a term describing the property of biomass to retain ions, mainly heavy metals and radionuclides. The biosorption mechanism depends on whether the organisms are living or dead, the type of 
microorganism and conditions of performed process: temperature, $\mathrm{pH}$, biomass concentration and metal ions concentration. The main differences in mechanisms of binding metals ions are the type of the biomass (living or dead) are shown in Fig. $1^{[32,33]}$.

The bioaccumulation of heavy metals is closely connected with their toxicity, i.e. restraining microorganism's metabolism and growth. Low concentrations of heavy metal ions are necessary for the vitality of all microbial cells and certain low concentrations of $\mathrm{Cu}$ and $\mathrm{Zn}$ even stimulate the growth and the activity of the metabolic processes. At high heavy metals concentration the growth may be severely restrained which can be observed as a prolonged lagphase $^{[34,27]}$.

Both, biosorption and bioaccumulation can be described by isotherm equations ${ }^{[35-43]}$. Mechanism of proposed method of binding metal ions to cell surface is mainly ion exchange, in which microelements are exchanged to microelement cations. As a result of this phenomenon, the concentration of alkali and alkaline earth metal ions is higher as it was before biosorption or bioaccumulation process. As a result of taking up microelement ions by microalgal biomass, other ions are released ${ }^{[44,45]}$.
Elaboration of the production technology of such feed additives with microelements for livestock from algae is an important issue to consider. Thus, one of the technological problems that need to be solved is to find the efficient way of elimination of alkali and alkaline earth metal ions, to make the process a closed cycle and waste-less technology. Proposed technological process assumed recycling of biosorption solution to reduce environmental impact, but the question is how many times the remaining solution can be reused.

Two possible ways of obtaining mineral feed additives are considered (Fig. 2). The biosorption and

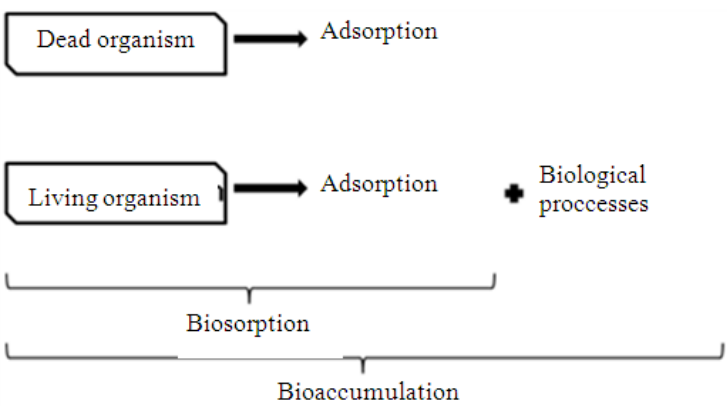

Fig. 1: Biosorption and bioaccumulation

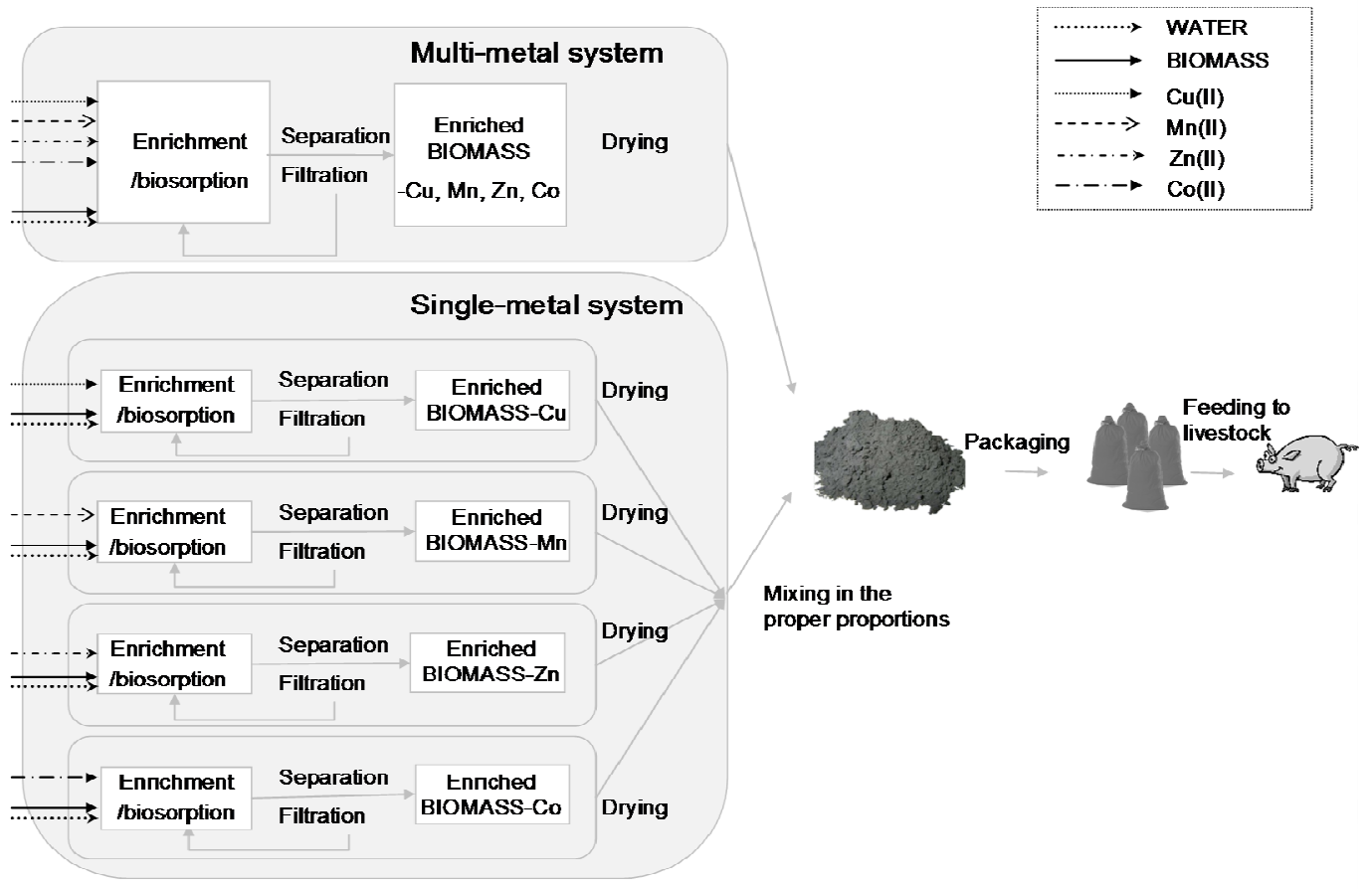

Fig. 2: Flowchart of bisorption in single and multi metal system 
bioaccumulation processes can be performed in two configurations, single-metal system and multi-metal system. In single-metal system biomass is enriched in each ions individually at a time. The process is more complicated, but on the other hand easier to control and predict. However, in the case of multi-metal system it would be easier technologically, since the biomass would be enriched with all the microelements simultaneously, in a single process.

Microalgae in terms of sustainable production: In September 1999, Chad Holliday (DuPont's CEO) announced: 'We will take important steps toward the use of renewable resources and energy. The goal is to source $10 \%$ of our energy needs in the year 2010 from renewable energy sources and to derive $25 \%$ of our revenues in 2010 from areas other than those requiring finite raw materials ${ }^{[46]}$. Most of utilized mineral feed additives nowadays are used from non renewable sources. Utilization of microalgae as a base to produce such a feed additives cause less mineral mining, as a result of better bioavailability of minerals supplied in biological form. The concept of using biological pathways to produce a wide variety of valuable compounds offers many opportunities for innovative products in the areas of nutrition in agriculture.

MBR technology: The aim of this review is to assess the potential applications of membrane technology in the agriculture and to find out if membrane bioreactor is a suitable method to separate the enriched biomass from the reaction mixture and to propose the most suitable process flowchart. Choosing the efficient separation methods is important for a broad range of these research areas. Key factors that have an impact on the choice of separation strategy include process throughput, particle size of the product and impurities and the desired end-product concentration ${ }^{[47]}$. The development of efficient, economical and selective separation methods will be required for successful commercialization of bioprocesses ${ }^{[46]}$. Separation of biologically based products often needs entirely new processes to handle unusual material properties, such as the compressibility of a biomass. Effort involved in thermal and chemical separation techniques is higher than that in mechanical techniques (filtration, centrifugation, clarification, membranes, classification, purification, agglomeration, washing $)^{[48]}$. Membrane bioreactors which are usually applied to treat industrial wastewater in this study are discussed as a method to separate a valuable biomass of enriched microalgae and reuse the solution with residual metal ions that can be used once again in the next biosorption process.

Membrane Bioreactors (MBRs) were first developed 40 years ago and have been used commercially in Japan for almost 30 years. Since 1990, MBR technology has been brought to North America and Europe and is now experiencing rapid growth in a wide variety of applications ${ }^{[49]}$.

Membrane bioreactor technologies are, as the name suggests, those technologies that provide biological processes with membrane separation. Currently, two of the most significant components of MBR operation costs are membrane replacement and energy consumption and both relate with fouling ${ }^{[50]}$. From extensive research of scientific literature, there was strong evidence that membrane bioreactor posses huge potential of application and not only in the industrial wastewater treatment ${ }^{[51]}$.

MBR technology is becoming more common due to its advantages of superior effluent quality, absolute control of solids and hydraulic retention times and smaller volume and footprint ${ }^{[52]}$. Membrane-coupled bioreactors (MBRs) are an attractive design for the treatment of municipal and industrial wastewaters. The MBR design is analogous to that of the activated sludge process, except that more efficient biomass retention (up to 100\%) is achieved through the use of a membrane with a small pore size. MBR offer substantially improved treatment performance because the effluent is virtually cell-free ${ }^{[53]}$.

The global Membrane Bioreactors (MBR) market is rising at an Average Annual Growth Rate (AAGR) of $10.9 \%$ and is expected to approach US\$ 363 million in 2010. Experts believe that Membrane Bioreactor (MBR) technology offers the ultimate opportunity to improve filtration and separation efficiencies ${ }^{[48]}$. MBR technology is considered as a way of achieving zero untreated liquid discharge ${ }^{[3]}$. The membranes may be made of different kinds of materials depending on the system that is being used to separate the fluid mixture ${ }^{[46]}$.

Membrane technology has been extensively applied to various industrial fields and has a number of advantages $^{[54,55]}$ :

- There is no need to add other chemical substances

- It can generally operate at ambient temperatures

- It requires only simple equipment and small volumes

- It has low energy consumption and convenient maintenance 


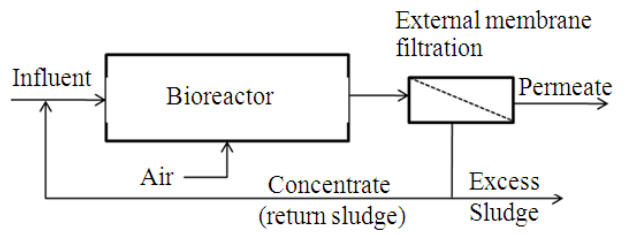

(a)

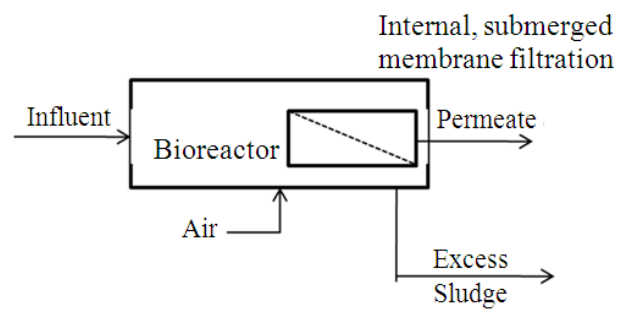

(b)

Fig. 3: The submerged (a): System and the external (b): Membrane filtration ${ }^{[56]}$

Membrane filtration is a strictly physical, absolute separative technique whose quality performance depends only on the membrane pore size ${ }^{[56]}$. Two main MBR designs exist with the membrane module (Fig. 3) either located externally to the bioreactor (side stream) or immersed directly into it (submerged) ${ }^{[57]}$.

As with any new technology, unforeseen problems arise in long-term operation. Among a lot of technological problems of MBR systems, like lower membrane permeability that anticipated, bioreactor temperature impacting performance, the membrane fouling and need for rigorous membrane cleaning play the most important role in performance of $\mathrm{MBR}^{[49]}$.

A serious problem for membrane processes in any application is fouling. In MBR systems, membrane fouling is due to the complex interactions between the membrane material and the numerous components of the activated sludge mixed liquor. Controlling fouling, by backwashing, aeration or cleaning is therefore one of the key operating considerations for MBR systems ${ }^{[58]}$.

Membrane fouling has been widely considered to be one of the major limitations to faster commercialization of MBR, due to the fact that fouling reduces membrane filtration process ${ }^{[59]}$ :

- Productivity

- Shortens membrane lifespan

- Increase operational cost

Currently, MBRs tend to be operated with long Solids Retention Times (SRT) (from 25-3500 d) to maintain high biomass concentrations, reduce solids production and minimize reactor volume. As a result, biomass (mixed liquor) concentrations in MBRs range from 10,000 up to $50,000 \mathrm{mg} \mathrm{L}^{-1}$, often with no biomass wasting ${ }^{[52]}$.

It was found that biomass composition and structure in MBR is considerably different from a Conventional Activated Sludge (CAS). In activated sludge, non flocculating microorganisms are not retained in the system while in an MBR both flocforming and dispersed microorganisms are retained.

Thus, detailed knowledge regarding the sludge characteristics and microbial community, as well as membrane properties, is necessary to the better understand system failure and membrane fouling ${ }^{[60]}$. Due to the high organic matter and salt removal efficiencies of the NF (nanofiltration) membrane, the NF MBR is expected to result in a microbial community diversity that would be different to that of the MF (microfiltration) and UF MBRs. The NF MBR will expose the microorganisms to conditions in which the concentrations of organic matter, particularly refractory organic compounds and salt were relatively higher.

The examples of removal efficiency of MBR are presented in Table 3.The researchers demonstrated that MBRs can be effectively designed to remove both carbonaceous and nitrogenous pollutants with high efficiency, more than $90 \%{ }^{[62]}$.

Because it is highly efficient, energy saving and creates no public nuisance, membrane technology and its equipment have become one of industry's most important techniques, it now has important economic and technical values and is therefore developing quickly and can be effectively applied in the development and utilization of biomass resources. Membrane technology gained acceptance in the foodprocessing industry and has many potential applications in agriculture ${ }^{[68]}$.

The productivity of dry wine in the double-vessel membrane bioreactor was 28 times higher than that in the batch fermentation ${ }^{[70]}$. In comparison with batch fermentation, membrane bioreactors achieve remarkably elevated cell concentrations and productivity. In this type of bioreactor, a membrane has been installed to prevent washout of yeast when broth is withdrawn from the reactor. The high-performance membrane bioreactor has been studied in fields such as ethanol fermentation, organic acid fermentation, including lactic acid fermentation and waste water treatment $^{[69-71]}$. 
Table 3: Examples of removal efficiency of MBR

\begin{tabular}{|c|c|c|c|}
\hline Membrane & Removal efficiency (\%) & Effluent & References \\
\hline $\begin{array}{l}\text { Lab scale submerged MBR } \\
\text { M }\end{array}$ & TCOD-97.3-98 & Synthetic wastewater (total COD $400 \mathrm{mg} \mathrm{L}^{-1}$ ) & [61] \\
\hline Pilot-scale MBR (MF) submerged & $\begin{array}{l}\text { Clofibric acid-86 } \\
\text { Ibuprofen-98 } \\
\text { Mefenamic acid-70 } \\
\text { Fetoprofen-97 } \\
\text { Naproxen -86 }\end{array}$ & Pharmaceutically active compounds $\mathrm{PhACs}$ & [62] \\
\hline Lab-scale MBR & $\begin{array}{l}\text { TCOD-94.2 } \\
\text { TBOD-99.7 }\end{array}$ & Pet food wastewater & [63] \\
\hline Submerged MBR & $\begin{array}{l}\text { COD-94 } \\
\text { TN-74 } \\
\mathrm{NH}_{3}{ }^{+}-\mathrm{N}-91\end{array}$ & Original food processing wastewater & [64] \\
\hline $\begin{array}{l}\text { MBR with MIA (Modified } \\
\text { Intermittent aeration) }\end{array}$ & $\begin{array}{l}\text { COD-95.2 } \\
\text { BOD }_{5}-98.2 \\
\text { TN-72.7 } \\
\text { TP-71.4 } \\
\text { E. coli-99.9 }\end{array}$ & Sewage from sari town, Chungbuk. Korea & [65] \\
\hline MBR (UF) & $\begin{array}{l}\text { BOD }_{5-53} \\
\text { COD-56 } \\
\text { TN-99 }\end{array}$ & Laundry wastewater & [66] \\
\hline MBR (UF) pilot scale & $\begin{array}{l}\text { BOD }_{5}-21 \\
\text { COD-42 } \\
\mathrm{NH}_{3}{ }^{+}-\mathrm{N}-66\end{array}$ & Wastewater after textile printing & [67] \\
\hline
\end{tabular}

MBR in microalgal technology: Production of microalgae-derived products as mineral feed additives requires processes for cultivation of alga, enrichment process and afterwards recovery of the enriched biomass from the solution to obtain free-cell liquid that could be reused in the next process. As with many microbial processes for producing bioactive, the downstream recovery of algal products can be substantially more expensive than the culturing of the alga. Recovery of the biomass from the broth has been claimed to contribute $20-30 \%$ to the total cost of producing the biomass. Biomass can be separated by centrifugation, filtration or in some cases, gravity sedimentation. These processes may be preceded by a flocculation step. Recovery of biomass can be a significant problem because of the small size $(3-30 \mu \mathrm{m}$ diameters) of the algal cells. Reaction broths are generally relatively diluted $\left(<0.5 \mathrm{~kg} \mathrm{~m}^{-3}\right.$ dry biomass in some commercial production systems) and hence large volumes need to be handled to recover the biomass ${ }^{[72]}$. The preference of the algae separation methods depends on the species of algae, chemistry of growth medium, ultimate use of algal biomass and most economically available separation technology. The size of algal cells is an important factor to consider while selecting the technique of separation. Colonial algae and filamentous algae (Spirulina) could be harvested by low-cost separation technology such as sedimentation, flotation and filtration. Smaller microalgae, like most single-cell (Chlorella) and motile algae (Euglena, Chlorognium), have to be flocculated before their gravity separation. Gravity sedimentation as a low-cost technology and is usually considered first to clarify the dilute algal suspension, but on the other hand poor removal efficiency is obtained ${ }^{[73]}$.

A further consideration in selecting a suitable harvest method is the acceptable level of moisture in the product. Gravity sediment sludge is generally more dilute than centrifugally recovered biomass. Too much moisture in the harvested biomass can substantially influence the economics of product recovery downstream, if dehydration of the biomass is required after harvest. Because thermal drying is more expensive than mechanical dewatering, thermal drying should be proceeded by a mechanical dewatering step such as filtration or centrifugation ${ }^{[74]}$.

Membrane technology is suitable for that application and becomes now attractive in biotechnology for industrial exploitation. Cross-flow microfiltration and ultrafiltration techniques have become a suitable process for the separation of microorganisms in a variety of biotechnical applications ${ }^{[75]}$. Both Microfiltration (MF) and Ultrafiltration (UF) have been used to remove microorganisms also microalgae from drinking water with very good results. Membrane filtration is strictly physical, absolute separative technique whose quality performance depends only on the membrane pore size ${ }^{[56,76]}$.

\section{DISSCUSION}

The project of process of production of mineral feed additives based on microalgal biomass with traditional methods of separation is shown in Fig. 4. 


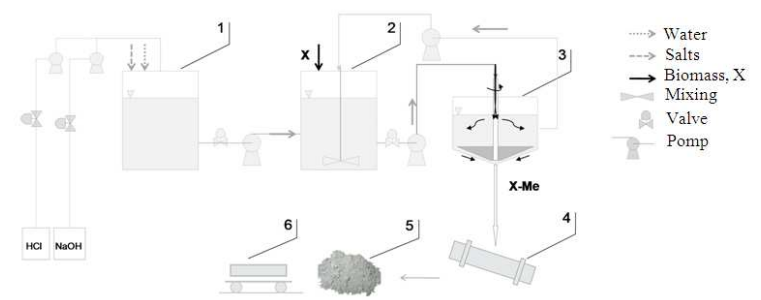

Fig. 4: Flowchart of the production of mineral feeds additives based on algal biomass. (1): Solution of inorganic salts $\mathrm{MnSO}_{4} \cdot 5 \mathrm{H}_{2} \mathrm{O}, \mathrm{CuSO}_{4} \cdot 5 \mathrm{H}_{2} \mathrm{O}$, $\mathrm{Co}\left(\mathrm{NO}_{3}\right)_{2} \cdot 6 \mathrm{H}_{2} \mathrm{O}, \quad \mathrm{ZnSO}_{4} \cdot 7 \mathrm{H}_{2} \mathrm{O}$, all in one container (multi-metal system), or each in separated containers (single metal system), (2): Reactor/biosorbers (here biosorption process take place), (3): Sedimentation tank (here separation of the biomass from permeate take place), (4): Dryer, (5): Mineral feed additives, enriched biomass (X-Me), (6): Transport/selling ${ }^{[77]}$

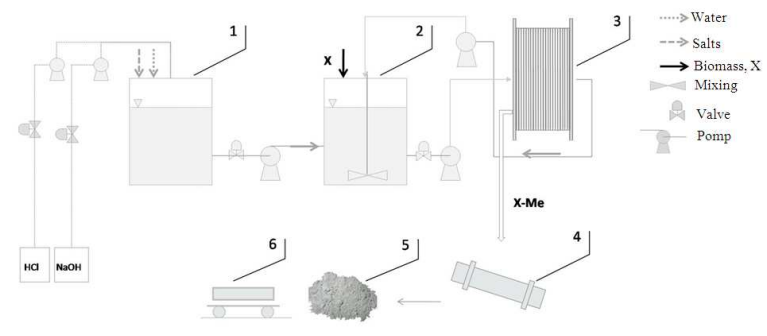

Fig. 5: Flowchart of proposition of the production of mineral feeds additives based on algal biomass with membrane as a method of separation. (1): Solution of inorganic salts $\mathrm{MnSO}_{4} \cdot 5 \mathrm{H}_{2} \mathrm{O}$, $\mathrm{CuSO}_{4} \cdot 5 \mathrm{H}_{2} \mathrm{O}, \mathrm{Co}\left(\mathrm{NO}_{3}\right)_{2} \cdot 6 \mathrm{H} 2 \mathrm{O}, \mathrm{ZnSO}_{4} \cdot 7 \mathrm{H}_{2} \mathrm{O}$, all in one container (multi-metal system), or each in separated containers (single metal system), (2): Reactor/biosorbers (here biosorption process take place), (3): Membrane module (here separation of the biomass from permeate take place), (4): Dryer, 5-mineral feed additives, enriched biomass (X-Me), (6): Transport/selling

For better understanding the whole idea, only biosorption process was taken into consideration. In the case of bioaccumulation additional bioreactor (photobioreactor should be used), where the cultivation of the biomass would take place. That tank should be illuminated and appropriate ratio of inorganic salt should be used as a culture medium which is necessary

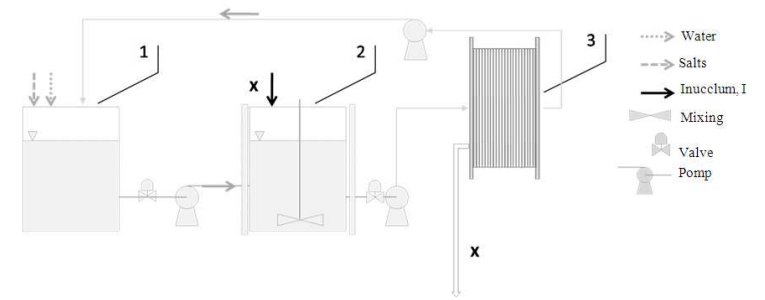

Fig. 6: Proposition of harvesting of microalgae with application of membrane module as separation method. (1): Solution of culture medium (2): Photobioreactor with illumination, (3): Membrane module (here separation of the biomass from medium take place)

for efficient cultivation of microalgae. In this study it is assumed that biomass will be produced in a separated process. And as a natural biomass with inactive metabolism will be added in to the main production process, which is marked as $\mathrm{X}$ in the Fig. 4 and 5.

The whole enrichment process consists of several main steps. In first a reaction mixture of a given metal or metal ions, (using inorganic salts that are commonly used in agriculture as the source of micronutrients in animal feeding), with adjusted $\mathrm{pH}$ is pumped to a biosorber where metal ions are bound to the biomass (nr 2 in Fig. 4). Then suspension with algal cells is pumped to sedimentation tank where separation takes place. The biomass is collected as sludge from the bottom and moved to a dryer.

The membrane module applied in production process is going to be used as a separation method. The Fig. 5, presents new configuration of the process with utilization of membrane as a method of separation of product which is in this case a biomass enriched with microelements. Introduction of membrane module into production process makes it possible to reuse the biosorption solution with high efficiency. Natural biomass is pumped to the 2nd container (no. 2, Fig. 5), where only biomass, water and salts solution are added. After given retained time enriched biomass is separated from the solution of inorganic salt and directed to the dryer. That proposal implies that the external configuration of membrane module is better in terms of quality of broth, although the energy cost will be significantly higher. External configuration is better in terms of process control. For better efficiency of enrichment process, it is necessary to separate the bioreactor from the membrane module.

The membrane module could be used in preparation of natural biomass that will be used in enrichment process which is shown in Fig. 4 and 5. MBR can be used to separate the natural biomass from 
preliminary step where photobioreactor is used (Fig. 6). In this case the membrane serves as a separator of fresh biomass from the growth medium (Fig. 6).

Vessel 1 in Fig. 6 contains medium (inorganic salts). In the next step, solution is pumped to the second container which is illuminated and where inoculums of microalgal strains is added. Here growth of microalgae takes place. Cultivated biomass is pumped to the membrane module where separation takes place. Permeate is pumped to the first container. Line that connects the membrane module (3, Fig. 6) and the container with culture medium (1, Fig. 6) describes the possibility of returning of used medium after supplementation of substrate. However, during cultivation of algae cells released metabolites which can inhibit growth of microalgae. For this reason it is necessary to examine the possible number of recycling steps.

\section{CONCLUSION}

Agriculture profoundly affects many ecological systems. Negative effects of current practices include the accumulation of microelements in topsoil as the effect of low availability of nutrients in fodder additives applied in $\operatorname{diet}^{[8]}$.

The modern genetic improvement by selective breeding has resulted in today's highly fruitful breeds' of domestic animals and birds. But they demand high bioavailable nutrients in fodder to ensure their intensive growth and reproductive potential. Their mineral nutrition is especially important in this respect. Today more and more inorganic substances, which have limited absorption in gastrointestinal tract and create ecological problems, are supplied from organic mineral sources.

Introduction of new generation of mineral feed additives based of microalgal biomass in terms of sustainable agriculture is promising ${ }^{[30]}$. However, it is necessary to take into account all steps of the production process and to introduce proecological solutions that will reduce environmental impact of the production. Production of microalgae-derived products as mineral feed additives requires processes for cultivation o alga, enrichment process and afterwards recovery of the enriched biomass from solution to obtained free-cell liquid that could be reused in the next process $^{[31]}$.

Two methods of binding of metal ions to biomass of microalgae are proposed: biosorption and bioaccumulation. Biosorption is performed with cells with inactive metabolism, whereas bioaccumulation is performed with cells with active metabolism. Mechanism of proposed method of binding metal ions to cell surface is mainly ion exchange, in which macro elements are exchanged to microelement cations ${ }^{[19,44,45]}$.

Taking into consideration care about the environment it is better to applied membrane modules in the production process in terms of sustainable production. Although higher costs are required at the same time lower volumes of effluents are generate. For better understanding the problem it is necessary to perform detailed economical analysis of the possible configuration. But at the same time with no doubt it can be said that the application of membrane modules creates less direct inputs to the environment. Considering the higher costs of drying the sludge in the case of traditional technology of separation it may be economically beneficial to take into consideration all membrane modules which require less costs than the sedimentation $\operatorname{tank}^{[78]}$.

The proposed solution assumed the application of membrane modules as a separation step after enrichment process. As a result cells-free permeate is obtained which can be used once again as a solution of salt of microelements in subsequent biosorption process. Another solution uses membrane module in production of natural biomass of microalgae as a method that allows to obtain natural biomass and cellfree permeate of medium solution.

\section{REFERENCES}

1. Kroyer, G.T., 1995. Impact of food processing on the environment an overview. Lebensm. Wiss. U. Technol., 28: 547-552. http://cat.inist.fr/?aModele $=$ afficheN and cpsidt $=2952462$

2. Dach, J. and D. Starmans, 2005. Heavy metals balance in Poland and Dutch agronomy: Actual state and previsions for the future. Agric. Ecosyst. Environ., 107: 309-316. http://cat.inist.fr/?aModele $=$ afficheN and cpsidt $=16743007$

3. Weiss, M., M. Patel, H. Heilmeier and S. Bringezu, 2007. Applying distance-to-target weighing methodology to evaluate the environmental performance of bio-based energy, fuels and materials. Res. Conservat. Recycl., 50: 260-281. DOI: 10.1016/j.resconrec

4. Kim, S. and B.E. Dale, 2006. Ethanol Fuels: E10 or E85-life cycle perspectives. Int. J. Life Cycle Assess., 11: 117-121. DOI: 10.1065/lca 
5. Gavrilescua, M. and Y. Chisti, 2005. Biotechnology-a sustainable alternative for chemical industry. Biotechnol. Adv., 23: 471-499. DOI: 10.1016/j.biotechadv

6. Our Common Future, The Bruntland Commission, UNESCO, 1987. World Commission on Environmental Development. http://www.undocuments.net/wced-ocf.htm

7. Newman, L., 2005. Uncertainty, innovation and dynamic sustainable development. Sustain.: Sci., Pract. Policy, 1: 25-31. http://ejournal.nbii.org/archives/vol1iss2/0501001.newman.html

8. Norgate, T.E., S. Jahanshahi and W.J. Rankin, 2006. Assessing the environmental impact of metal production process. J. Clean. Prod., 15: 838-848. DOI: 10.1016/j.jclepro.2006.06.018

9. Jondreville, C., P.S. Revy and J.Y. Dourmand, 2003. Dietary means to better control the environmental impact of copper and zinc by pigs from weaning to slaughter. Livest. Prod. Sci., 84: 147-156. DOI: 10.1016/j.livprodsci

10. Berger, L.L., 2006. Salt and Trace Minerals for Livestock, Poultry and Other Animals. Salt Institute, Alexandria, VA. http://www.saltinstitute.org/content/download/476/ 2964/file/redbook.pdf

11. Kegley, E.B. and J.W. Spears, 1994. Bioavailability of feed-grade copper sources (oxide, sulfate, or lysine) in growing cattle. J. Anim. $\quad$ Sci., 72: 2728-2734. http://jas.fass.org/cgi/reprint/72/10/2728.pdf

12. Miles, R.D. and P.R. Henry, 2000. Relative trace mineral bioavailability. Ciên. Anim. Bras., 1: 73-93. http://revistas.ufg.br/index.php/vet/article/viewFile/ 252/223

13. Sandoval, M., P.R. Henry, C.B. Ammerman, R.D. Miles and R.C. Littell, 1997. Relative bioavailability of supplemental inorganic zinc sources for chicks. J. Anim. Sci., 75: 3195-3205. http://jas.fass.org/cgi/reprint/75/12/3195.pdf?ck = nck

14. Guo, R., P.R. Henry, R.A. Holwerda, J. Cao, R.C. Littell, R.D. Miles and C.B. Ammerman, 2001. Chemical characteristics and relative bioavailability of supplemental organic copper sources for poultry. J. Anim. Sci., 79: 1132-1141. http://jas.fass.org/cgi/reprint/79/5/1132.pdf?ck = nck

15. Wedekind, K.J., A.J. Lewis, M.A. Giesemann and P.S. Miller, 1994. Bioavailability of zinc from inorganic and organic sources for pigs fed cornsoybean meal diets. J. Anim. Sci., 72: 2681-2689. http://jas.fass.org/cgi/content/abstract/72/10/2681
16. Appendix IV, 1998. Environmental data summary, environmental impacts of animal feeding operations, US environmental protection agency. http://milk.procon.org/sourcefiles/Impacts-AnimalFeeding-Operations.pdf

17. Ecological Farming May Cause More Heavy Metals In The Soil, article on line. http://www.scienceagogo.com/news/19990109225 423data_trunc_sys.shtml

18. Haye, S., V.I. Slaveykova and J. Payet, 2007. Terrestial ecotoxicity and effect factors of metals in Life Cycle Assessment (LCA). Chemosphere, 68: 1489-1496. DOI: 10.1016/j.chemosphere

19. Kadukova, J. and E. Vircikova, 2005. Comparison of differences between copper bioaccumulation and biosorption. Environ. Int., 31: 227-232. DOI: 10.1016/j.envint

20. Donmez, G.C., Z. Aksu, A. Ozturk and T. Kutusal, 1999. A comparative study on heavy metal biosorption characteristics of some algae. Process Biochem., 34: 885-892. DOI: 10.1016/S00329592(99)00005-9

21. Aksu, Z., 2001. Equilibrium and kinetic modeling of cadmium(II) biosorption by $C$. vulgaris in a bath system: Effect of temperature. Sep. Purificat. Technol., 21: 285-294. DOI: 10.1016/S13835866(00)00212-4

22. Oporto, C., O. Arce, V.E. Broeck, V.B. Bruggen and C. Vandecasteele, 2006. Experimental study and modeling of $\mathrm{Cr}(\mathrm{VI})$ removal from wastewater using lemna minor. Water Res., 40: 1458-1464. DOI: $10.1016 /$ j.watres

23. Kargi, F. and S. Cikla, 2006. Biosorption of zinc (II) ions onto Powdered Waste Sludge (PWS): Kinetics and isotherms. Enz. Microb. Technol., 38: 705-710. DOI: 10.1016/j.watres.2006.01.037

24. Gong, R., Y. Ding, H. Liu, Q. Chen and Z. Liu, 2005. Lead biosorption and desorption by intact and pretreated Spirulina Maxima biomass. Chemosphere, 58: 125-13. DOI: 10.1016/j.chemosphere.2004.08.055

25. Yan, H. and G. Pan, 2002. Toxicity and bioaccumulation of copper in three green microalgae species. Chemosphere, 49: 471-476. DOI: 10.1016/S0045-6535(02)00285-0

26. Saygideger, S., O. Gulnaz, E.S. Istifli and N. Yucel, 2005. Adsorption of $\mathrm{Cd}(\mathrm{II}), \mathrm{Cu}(\mathrm{II})$ and $\mathrm{Ni}(\mathrm{II})$ ions by lemna minor L. effect of physicochemical environment. J. Hazard. Mater., 126: 96-104. DOI: 10.1016/j.jhazmat.2005.06.012 
27. Pavasant, P., R. Apiratikul, V. Sungkhum, P. Suthiparinyanont, S. Wattanachira and T.F. Marhaba, 2006. Biosorption of $\mathrm{Cu}^{2+}, \mathrm{Cd}^{2+}$, $\mathrm{Pb}^{2+}$ and $\mathrm{Zn}^{2+}$ using dried marine green macroalga Caulerpa lentillifera. Bioresour. Technol., 97: 2321-2329. DOI: 10.1016/j.biortech.2005.10.032

28. Akar, T. and S. Tunali, 2006. Biosorption characteristics of aspergillus flavus biomass for removal of $\mathrm{Pb}$ (II) and $\mathrm{Cu}$ (II) ions from an aqueous solution. Bioresour. Technol., 97: 1780-1787. DOI: 10.1016/j.biortech.2005.09.009

29. Chojnacka, K., A. Chojnacki and H. Górecka, 2004.Trace element removal by Spirulina sp. from copper smelter and refinery effluents. Hydrometallurgy, 73 : 147-153. DOI: 10.1016/j.hydromet.2003.10.003

30. Michalak, I., A. Zielińska, K. Chojnacka and J. Matuła, 2007. Biosorption of $\mathrm{Cr}$ (III) by microalgae and macroalgae: Equilibrium of the process. Am. J. Agric. Biol. Sci., 2: 284-290. http://www.scipub.org/fulltext/AJAB/AJAB24284290.pdf

31. Chojnacka, K., 2007. Biosorption and bioaccumulation of microelements by Riccia fluitans in single and multi-metal system. Bioresour. Technol., 98: 2919-2925. DOI: 10.1016/j.biortech.2006.10.001

32. Andrade, A.D., M.C.E. Rollemberg, J.A. Nóbrega, 2005. Proton and metal binding capacity of the green freshwater alga chaetophora elegans. Process Biochem., 40: 1931-1936. DOI: 10.1016/j.procbio.2004.07.007

33. Madrid, Y. and C. Camara, 1997. Biological substrates for metal preconcentration and speciation. Trends Anal. Chem., 16: 36-44. DOI: 10.1016/S0165-9936(96)00075-1

34. Mihova, St. and T. Godjevargova, 2000. Biosorption of heavy metals from aqueous solutions. J. Int. Res. Pub., 1: 34-42. http://www.ejournalnet.com/Contents/Issue_1/6/6_ 2001.htm

35. Aksu, Z., 2002. Determination of the equilibrium, kinetic and thermodynamic parameters of the batch biosorption of nickel(II) ions onto Chlorella vulgaris. Process Biochem., 38: 89-99. DOI: 10.1016/S0032-9592(02)00051-1

36. Gokhale, S.V., K.K. Jyoti and S.S. Lele, 2008. Kinetic and equilibrium modeling of chromium (VI) biosorption on fresh and spent Spirulina platensis/Chlorella vulgaris biomass. Bioresour. Technol., 99: 3600-3608. DOI: 10.1016/j.biortech.2007.07.039
37. Davis, T.A., B. Volesky and A. Mucci, 2003. A review of the biochemistry of heavy metal biosorption by brown algae. Water Res., 37: 4311-4330. DOI: 10.1016/S0043-1354(03)00293-8

38. Sag, Y., A. Kaya and T. Kutsal, 1998. The simultaneous biosorption of $\mathrm{Cu}$ (II) and $\mathrm{Zn}$ on Rhizopus arrhizus: Application of the adsorption models. Hydrometallurgy, 50: 297-314. DOI: 10.1016/S0304-386X(98)00065-6

39. Tuzun, I., G. Bayramoglu and E. Yalçn, 2005. Equilibrium and kinetic studies on biosorption of $\mathrm{Hg}(\mathrm{II}), \mathrm{Cd}(\mathrm{II})$ and $\mathrm{Pb}(\mathrm{II})$ ions onto microalgae Chlamydomonas reinhardtii. J. Environ. Manage., 77: 85-92. DOI: 10.1016/j.jenvman.2005.01.028

40. Mameri, N., N. Boudries, L. Addour, D. Belhocine, H. Lounici, H. Grib and A. Pauss, 1999. Batch zinc biosorption by a bacterial nonliving Streptomyces rimosus biomass. Water Res., 33: 1347-1354. DOI: 10.1016/S0043-1354(98)00349-2

41. Sag, Y. and T. Kutsal, 2000. Determination of the biosorption activation energies of heavy metal ions on Zoogloea ramigera and Rhizopus arrhizus. Process Biochem., 35: 801-807. DOI: 10.1016/S0032-592(99)00154-5

42. Çabuk, A., T. Akar, S. Tunali and S. Gedikli, 2007. Biosorption of $\mathrm{Pb}(\mathrm{II})$ by industrial strain of Saccharomyces cerevisiae immobilized on the biomatrix of cone biomass of Pinus nigra: Equilibrium and mechanism analysis. Chem. Eng. J., 131: 293-300. DOI: 10.1016/j.cej.2006.12.011

43. Arca, M.Y., I. Tüzün, E. Yalçn, Ö. Ince and G. Bayramoglu, 2005. Utilisation of native, heat and acid-treated microalgae Chlamydomonas reinhardtii preparations for biosorption of $\mathrm{Cr}(\mathrm{VI})$ ions. Process Biochem., 40: 2351-2358. DOI: 10.1016/j.procbio.2004.09.008

44. Crist, R.H., J.R. Martin and J. Chonoko, 1996. Uptake of metals on peat moss: An ion-exchange process. Environ. Sci. Technol., 30: 2456-2461. DOI: $10.1021 /$ es950569d

45. Crist, R.H., J.R. Martin and D.R. Crist, 2002. Heavy metal uptake by lignin: Comparison of biotic ligand models with an ion-exchange process. Environ. Sci. Technol., 36: 1485-1490. DOI: 10.1021/es011136f

46. Keller, K., T. Friedmann and A. Boxman, 2001. The bioseparation needs for tomorrow. Trends Biotechnol., 19: 438-441. DOI: 10.1016/S01677799(01)01803-0

47. Nancy, J.C. and J.F. Howard, 1992. Separation of components of the biomass from high rate algal ponds using Percoll $^{\mathrm{R}}$ density gradient centrifugation. J. Applied Phycol., 4: 1573-5176. DOI: $10.1007 / \mathrm{BF} 02442464$ 
48. Filtration industry review of the year, 2005. Filtrat. Ind. Analyst., 12: 1. DOI: 10.1016/S13656937(05)70954-0

49. Graeme, P., 2008. Introduction to membranes: An introduction to membrane bioreactors. Filtrat. Seperat., 45: 32-35. DOI: 10.1016/S00151882(08)70028-4

50. Juddv, S., 2008. The status of membrane bioreactor technology. Trends Biotechnol., 26: 109-116. DOI: 10.1016/j.tibtech.2007.11.005

51. Xiufen, L., L. Yanjun, L. He, H. Zhaozhe, D. Guocheng and C. Jian, 2007. Characteristics of aerobic biogranules from membrane bioreactor system. J. Membr. Sci., 287: 294-299. DOI: 10.1016/j.memsci.2006.11.005

52. Ng, H.Y. and S.W. Hermanowicz, 2005. Membrane bioreactor operation at short solids retention times: Performance and biomass characteristics. Water Res., 39: 981-992. DOI: 10.1016/j.watres.2004.12.014

53. LaPara T.M., C.G. Klatt and R. Chen, 2006. Adaptations in bacterial catabolic enzyme activity and community structure in membrane-coupled bioreactors fed simple synthetic wastewater. J. Biotechnol., 121: 368-380. DOI: 10.1016/j.jbiotec.2005.07.013

54. Bang-xiao, C., 2005. Membranes for process: Separation in food and biological engineering. Fiterat. Seperat., 42: 33-35. DOI: 10.1016/S00151882(05)70660-1

55. Ismail, A.F. and P.Y. Lai, 2001. Application of membrane separation in biotechnology. Proceedings of the National Biotechnology Seminar, (NBS'01), Malaysia, pp: 10-13. http://eprints.utm.my/5257/1/AhmadFauziIsmail20 01_ApplicationOfMembraneSeparationInBiotechn ology.pdf

56. Hung, M.T. and J.C. Liu., 2006. Microfiltration for separation of green algae from water. Colloids Surf., B, 51: 157-164. DOI: 10.1016/j.colsurfb.2006.07.003

57. Le-Clech, P., B. Jefferson and S.J. Judd, 2005. A comparison of submerged and sidestream tubular membrane bioreactor configurations. Desalination, 173: 113-122. DOI: 10.1016/j.desal.2004.08.029

58. Le-Clech, P., A. Fane, G. Leslie and A. Childress, 2005. MBR focus: The operators' perspective. Fiterat. Seperat., 42: 20-23. DOI: 10.1016/S00151882(05)70556-5

59. Yang, W., N. Cicek and J. Ilg, 2006. State-of-theart of membrane bioreactors: Worldwide research and commercial applications in North America. J. Membr. Sci., 270: 201-211. DOI: 10.1016/j.memsci.2005.07.010
60. Jae-Hoon, Ch. L.S. Hyon, F. Kensuke and Y. Kazuo, 2007. Comparison of sludge characteristics and PCR-DGGE based microbial diversity of nanofiltration and microfiltration membrane bioreactors. Chemosphere, 67: 1543-1550. DOI: 10.1016/j.chemosphere.2006.12.004

61. Ghosh, S. and T.M. LaPara, 2005. Removal of carbonaceous and nitrogenous pollutants from a synthetic wastewater using a membrane-coupled bioreactor. J. Ind. Microbiol. Biotechnol., 31: 353-361. http://cat.inist.fr/?aModele $=$ afficheN and cpsidt $=$ 16100655

62. Katsuki, K., H. Hiroe and W. Yoshimasa, 2005. Removal of pharmaceutical compounds by submerged Membrane Bioreactors (MBRs). Desalination, 178: 135-140. DOI: 10.1016/j.desal.2004.11.033

63. Kurian, R., C. Acharya, G. Nakhla and A. Bassi, 2005. Conventional and thermophilic aerobic treatability of high strength oily pet food wastewater using membrane-coupled bioreactors. Water Res., 39: 4299-4308. DOI: 10.1016/j.watres.2005.08.030

64. Ying, W., H. Xia and Y. Qipeng, 2005. Nitrogen and carbon removals from food processing wastewater by an anoxic/aerobic membrane bioreactor. Process Biochem., 40: 1733-1739. DOI: 10.1016/j.procbio.2004.06.039

65. Kim, H.S., I.S. Seo, Y.K. Kim, J.Y. Kim, H.W. Ahn and I.S. Kim, 2007. Full-scale study on dynamic state membrane bio-reactor with modified intermittent aeration. Desalination, 202: 99-105. DOI: 10.1016/j.desal.2005.12.044

66. Šostar-Turk, S., I. Petrinic and M. Simonic, 2005. Laundry wastewater treatment using coagulation and membrane filtration. Resour. Conserv. Recycl., 44: 185-196. DOI: 10.1016/j.resconrec.2004.11.002

67. Šostar-Turk, S., M. Simonic and I. Petrinic, 2005. Wastewater treatment after reactive printing. Dyes Pigments, 64: 147-152. DOI: 10.1016/j.dyepig.2004.04.001

68. Cano, À. and C. Palet, 2007. Xylooligosaccharide recovery from agricultural biomass waste treatment with enzymatic polymeric membranes and characterization of products with MALDI-TOFMS. J. Membr. Sci., 291: 96-105. DOI: 10.1016/j.memsci.2006.12.048

69. Takaya, M., N. Matsumoto and H. Yanase, 2002. Characterization of membrane bioreactor for dry wine production. J. Biosci. Bioeng., 93: 240-244. DOI: $10.1016 / \mathrm{S} 1389-1723(02) 80021-4$ 
70. Tomotani, J.E., L.C.M. Das Neves and M. Vitolo, 2005. Oxidation of glucose to gluconic acid by glucose oxidase in a membrane bioreactor. Appl. Biochem. Biotechnol., 121: 149-162. http://cat.inist.fr/?aModele $=$ afficheN and cpsidt $=$ 16828716

71. Choudhry, B. and T. Swaminathan, 2006. Lactic acid fermentation in cell-recycle membrane bioreactor. Applied Biochem. Biotechnol., 128: 171-183. http://www.springerlink.com/content/34602052376 x6584/

72. Grima, E.M., E.H. Belarbi, F.G. Acien Fernandez, A.R. Medina and Y. Chisti, 2003. Recovery of microalgae biomass and metabolites: Process options and economics. Biotechnol. Adv., 20: 491-515. DOI: 10.1016/S0734-9750(02)00050-2

73. Yakup, N. and W.J. Oswald, 1996. Tube settling of high-rate pond algae. Water Sci. Technol., 33: 229-241. DOI: 10.1016/0273-1223(96)00358-7

74. Aivasidis, A. and C. Wandrey, 1983. Different methods of biomass retention in continuous anaerobic digestion. Ann. New York Acad. Sci., 413: 486-488. DOI: 10.1111/j.17496632.1983.tb47928.x
75. Rossignol, N., L. Vandanjon, P. Jaouen and F. Que'me'neur, 1999. Membrane technology for the continuous separation microalgae: Culture medium: Compared performances of cross-flow microfiltration and ultrafiltration. Aquacult. Eng., 20: 191-208. DOI: 10.1016/S0144-8609(99)00018-7

76. Charcosset, C., 2006. Membrane processes in biotechnology: An overview. Biotechnol. Adv., 24: 482-492. DOI: 10.1016/j.biotechadv.2006.03.002

77. Zielińska, A., I. Michalak, K. Chojnacka and H. Górecki, 2007. New natural feed additives from microalgae and seaweeds enriched with microelements. Proceedings of the 2nd European Conference on Chemistry for Life Sciences, Sep. 4-8, Wroclaw, Poland, pp: 123-132. http://www.monduzzi.com/proceedings/moreinfo/2 0070906.htm

78. Market Report: MBR Technology, 2003. Filtrat. Ind. Analy., 7: 14. DOI: 10.1016/S13656937(03)00743-3 